\title{
Solid Waste Management: A Case Study of Malkapur City
}

\author{
Bhushan Dhamodkar $^{1}$, Yogesh V. Gawatre ${ }^{2}$, Dinesh W. Gawatre ${ }^{3}$, S. V. Dewalkar ${ }^{4}$ \\ ${ }^{1}$ M.E. Students Civil Engineering Department, PLIT, Buldana 443001 (M.S.), India \\ ${ }^{2}$ Sr. Engineer, SMS Infrastructure Ltd. Nagpur -440 001 (M.S.), India \\ ${ }^{3,4}$ Assistant Professor Civil Engineering Department, Sinhgad Academy of Engineering, Kondhwa (BK), Pune-411 048 (M.S.), India
}

\begin{abstract}
Solid wastes are being produced since the beginning of civilization. During the early period, solid wastes ware conveniently and unobtrusively disposed off, as the density of population was low with large open land space. With the advent of industrialization and urbanization, the problems of waste disposal increased.Sewage are a dilute mixture of the various type of waste from the residential, public and industrial place. The characteristics and composition of sewage mainly depend on this source. Sewage contains organic and inorganic matter which may by in dissolved, suspension and colloidal state. Usually large proportion of the waste matter. Solid waste also known as dry refuse includes house refuse, trade refuse and street refuse and is practically in a dry state.
\end{abstract}

Keywords: solid waste, Management, Garbage, Rubbish, Ash, Organic wastes, Inorganic waste

\section{Introduction}

High population density, intensive land use for residential, commercial and industrial activities laid to adverse impact on the environment. Environmental impact due to gaseous and liquid discharges has received greater attention than that by solid wastes. This is third pollution or land pollution (as it mainly affects the land) received limited public attention though it is significant. The term waste implies that it is of no concern to anyone and is of no value. The intrinsic value of at material as a resource or as an object of further utility has not been fully recognized. The net result is to produce expenditure involved for its disposal by mere allocation for resources. This does not mean that no expenditure is incurred for this purpose and it is reported that in some developed countries the expenditure incurred for solid waste management is quite substantial. The collection, transport, processing and disposal of solid wastes (which is a highly visible and important municipal service) involve a large expenditure but receive a scant attention. The citizens get accustomed to live with this nuisance though avoidable. The attention provided falls far short of the known and desired practice which could be attributed to public apathy, extended habits and traditions and vested interests leading to ineffective management.

\subsection{Picutre of Solid Waste Management (SWM) in Malkapur City}

Malkapur is one of the important cities in Buldhana district. It is one of the major industrialized cities in Buldhana district. It is situated at a distance of about $50 \mathrm{~km}$ from Buldhana well from Akola city. The local governing authority i.e. Nagar Parishad was established in 19 and in 2001 the population was 110687 souls. Since then its growth rate has been increasing.

Like other cities in India, Malkapur Nagar Parishad is looking forward for its expansion and development, giving basic amenities as per the needs of the city. But due to the increase in population and industrialization Malkapur city is now-a-days facing the problem of management of solid waste apart from water supply, roads etc. on an average every person generates more or less 250 to $300 \mathrm{gm}$ of solid waste every day. So the total generation of solid waste in Malkapur city is about 10.25 tons every day and is collected in 150 dustbin and some open spaces are provided in the service lanes. The quantity and quality of solid wastes differs from place to place i.e. sum area, old Malkapur city, expanded Malkapur, market, and so on. Malkapur city is facing problem of urban solid waste management i.e. insufficient facility of collection and transportation and no treatment and recycling. Solid waste is being collected and disposed of in landfills, Khaparkhed Shivar. Earlier this place was away from Malkapur city and now it is getting nearer to city due to expansion of city. This place is causing stinking and menacing condition to the nearby places. Mosquitoes, files are marking the life very difficult. From the above picture of Malkapur city it is clear that Malkapur city is facing problem in its solid waste management.

\section{Solid Waste Management}

Normally, the quantity of solid waste produced can be assessed accurately in house to house collection. But in Malkapur city due to absence of house to house collection the quantity of solid waste is assessed in an indirect manner. Garbage, Rubbish, Ash, Organic wastes, Inorganic waste.

It involves various activities associated with the management generation, storage, collection, transportation, processing and disposal of solid waste, which is environmentally compatible. It encompasses planning organization, administration, financial legal and engineering aspects involving interdisciplinary relationships, solid waste management involves interplay of 6 functional elements generation of waste, storage collection, transfer and transport, processing, recovery and disposal, Planning should be undertaken at local, state and national level for organizing an effective programmed. 


\section{International Journal of Science and Research (IJSR)}

ISSN (Online): 2319-7064

Index Copernicus Value (2013): 6.14 | Impact Factor (2014): 5.611

Outline of functional elements

A] Generation B] Storage C] Collection D] Transportation

E] Disposal

\section{Organization and Management}

\subsection{Organization structure of SWM in Malkapur city:-}

In Malkapur city the work of SWM is assigned to the "Health Department" of Malkapur Nagar Parishad. One of the objectives of this department is to collect, process and disposed the solid waste effectively at the least cost. This task has been divided into different workable parts such as section and division with specific authority and responsibility assigned to each, with co-ordination of all function. According to the health department organizational structure of SWM in Malkapur is as follows:-

Chief Officer

Municipal Council

Medical Health Officer

Table 1: Details of Prabhag offices in Malkapur city

\begin{tabular}{|c|c|c|c|c|}
\hline Prabhag no. & Office name & Population & $\begin{array}{c}\text { No of ward included } \\
\text { in each office }\end{array}$ & $\begin{array}{c}\text { Total area of } \\
\text { malkapur city }\left(\mathrm{km}^{2}\right)\end{array}$ \\
\hline Prabhag 1 & Chota bajar & 6470 & $1,2,3,4$ & \\
\hline Prabhag 2 & Nimwadi chowk & 6033 & $5,6,25$ & \\
\hline Prabhag 3 & Tahsil chowk & 7479 & $7,8,9,10$ & $11.28(\mathrm{KM} 2)$ \\
\hline Prabhag 4 & Birla Road & 6312 & $11,12,13,14$ & \\
\hline Prabhag 5 & In front of sub.district hospital & 6709 & $15,16,17,18$ & \\
\hline Prabhag 6 & Kulam khel area & 7145 & $19,20,21$ & \\
\hline Prabhag 7 & In front of Devi Mandir & 6754 & $22,23,24$ & \\
\hline
\end{tabular}

From each Prabhag office the data regarding the solid waste generated was collected. Table no. 2 shows the average quantity of solid waste generated in each Prabhag on daily basis

Table 2: Average quantity of SW generated in each Prabhag

\begin{tabular}{|c|c|}
\hline Prabhag Number & $\begin{array}{c}\text { Avg. qty. of solid waste generated } \\
\text { per day (in tons/day) }\end{array}$ \\
\hline 1 & 1.55 \\
\hline 2 & 1.38 \\
\hline 3 & 1.54 \\
\hline 4 & 1.32 \\
\hline 5 & 1.45 \\
\hline 6 & 1.58 \\
\hline 7 & 1.43 \\
\hline
\end{tabular}

From table no. 2, the quantity of SW generated in Malkapur city was found to be nearly 10.25 tons per day. These data refers to quantity of solid waste, which is actually coming in the storage bin system. According to the data from the Prabhag offices, the quantity of solid waste is known to vary seasonally. During the festival occasions, the amount of refuse shows an increase.

\section{Method of Investigation}

As the study was restricted to ,collection and transportation ${ }^{\text {ee }}$ of solid waste in Malkapur city, it was decided to find out those characteristics of solid waste which were significant from the collection and transportation point of view. Therefore it was decided to find out the physical characteristics of solid waste i.e. content of paper, plastic,
Contractor

Sanitary Inspector

Superintending

Contractor -Superintending

Medical Health Officer

Lab our - Sanitary Inspector

One foreman for each Ward Workers and sweepers

\subsection{Quantity of Solid Waste}

Normally, the quantity of solid waste produced can be assessed accurately in house to house collection. But in Malkapur city due to the absence of house to house collection the quantity of solid waste is assessed in indirect manner. For administration purpose, the Malkapur city is divided into 7 Prabhag officers, which in turn are subdivided into 29 wards. The table 1 shows information regarding all these Prabhag offices. metal, glass, bio-resistant, inert, biodegradable material in solid waste, moisture content of solid waste etc.

\subsection{Sample Collection}

To determine the physical characteristics of solid waste, the sample was required to be selected such that it would give the true representation of the occupation of the sub - group. For this purpose we have visited to the Khaparkhed Shivar, disposal site of Malkapur Nagar Parishad. At this station, vehicles after collecting all the solid waste from different parts of Malkapur city unload the solid waste with the help of tractor. Then on, it was decided to take the samples. On that day the samples of solid waste each of which weighing $10 \mathrm{Kg}$. and from different Prabhags from the Malkapur city were taken and the ward from which these samples showed the representation was noted. Thus, on that day, 3 samples from different Prabhag were taken. The same procedure of sampling was repeated on the next day. For 2 days the sampling has been done.

\subsection{Physical Analysis}

Samples so collected were sorted out physically into various ingredients such as paper, plastic, glass, metal, inert, bioresistant, biodegradable etc. on a sorting platform. The students sorted out the above given ingredients.

Then the individual components were separated and weighed by using the weighing balance. The weights were then expressed as the $\%$ of original sample. Thus the $\%$ of above stated ingredients was found out for each 7 Prabhags the 


\section{International Journal of Science and Research (IJSR) \\ ISSN (Online): 2319-7064}

Index Copernicus Value (2013): 6.14 | Impact Factor (2014): 5.611

average of the $\%$ of the tree sample was found out on the both days and present in tabular form. This table is as shown

below.

Table 3: Prabhag wise SW characteristics in Malkapur city

\begin{tabular}{|c|c|c|c|c|c|c|c|c|c|}
\hline Name of Prabhag & Day & $P A$ & $P L$ & $M E$ & $G L$ & $B R$ & $I N$ & $O T H$ & $B D$ \\
\hline Prabhag 1 & - & 13.6 & 12.41 & 8.73 & 6.22 & - & 1.53 & 5.53 & 52.38 \\
\hline Prabhag 2 & - & 14.82 & 14.67 & 6.20 & 4 & - & 1.68 & 4.69 & 53.94 \\
\hline Prabhag 3 & - & 16.5 & 13.8 & 5.37 & 4.68 & - & 1.81 & 6.03 & 52.41 \\
\hline Prabhag 4 & - & 17 & 13.51 & 5.26 & 4.51 & - & 1.53 & 5.42 & 52.57 \\
\hline Prabhag 5 & - & 16.62 & 14.53 & 3.5 & 3.64 & - & 1.81 & 5.5 & 54.42 \\
\hline Prabhag 6 & - & 17.68 & 14.16 & 1.66 & 0.66 & - & 0.83 & 6 & 59.61 \\
\hline Prabhag 7 & - & 16.30 & 17.25 & 2.64 & 2.5 & - & 3.53 & 6.08 & 52.62 \\
\hline
\end{tabular}

In Prabhag no. 6 the generation of biodegradable waste is more due to market area i.e. $80 \%$.

PA- Paper; PL- Plastic; ME- Metal; GL- Glass; BR- Bioresistant; IN- Inert; OTH- Others and BD- Biodegradable.

The table shows the average physical characteristics of solid waste on two different days. Then, the average of the $\%$ of solid waste of two was taken and than in turn the average \% of ingredient for Malkapur city was found out by taking the average of \% ingredient fro all the Prabhag and presented in following table:-

Table 4: Average characteristics percentage of SW in Malkapur city

\begin{tabular}{|c|c|c|c|}
\hline Ingredient & $\begin{array}{c}\text { Percentage } \\
\text { by weight }\end{array}$ & Ingredient & $\begin{array}{c}\text { Percentage } \\
\text { by weight }\end{array}$ \\
\hline Paper & 15.96 & Bio-resistant & - \\
\hline Plastic & 14.32 & Inert & 1.81 \\
\hline Metal & 4.75 & Others & 5.57 \\
\hline Glass & 3.64 & Biodegradable & 53.95 \\
\hline
\end{tabular}

All the above values are in percentages which are found wet weight basics:

- Bio resistant is including rubber, leather materials.

- Inert includes earth stone, ash.

- Others include broken pieces of furniture, tiles, and clothes.

- The above values are on wet- weight basis.

- Bio resistant means percentage of leather, rubber.

- Inert means percentage of soil.

- Others include percentage of pieces of furniture, woodwork, plywood, files, and clothes.

\subsection{Moisture content determination}

For this purpose the sample of $10 \mathrm{Kg}$ was reduced to $1 \mathrm{Kg}$ by conning method. In this method a heap of sample in the cone shape was prepared. Then this cone was divided into 4 parts and then, 2 diagonally opposite parts were taken and mixed while the other 2 parts were discarded. The sample was again mixed and a similar procedure was repeated, but this time the other diagonal parts were taken. The same procedure was continued till the sample was reduced to nearly $1 \mathrm{Kg}$. This sample was then used for moisture content determination. For moisture content determination, 6 parts of the sample were made and heated overnight at $100^{\circ} \mathrm{C}$ to obtain weight loss. This loss was expressed as a percentage loss of each part. Thus 6 readings of moisture content were obtained of which the average was taken. The following table shows the calculation of moisture content determination.

Table 5: Determination of Moisture Content

\begin{tabular}{|c|c|c|c|c|}
\hline $\begin{array}{c}\text { Sample } \\
\text { no. }\end{array}$ & $\begin{array}{c}\text { Wet weight } \\
\text { of sample } \\
w 1\end{array}$ & $\begin{array}{c}\text { Dry weight } \\
\text { of sample } \\
w 2\end{array}$ & $\begin{array}{c}\text { Moisture } \\
\text { content }(w 1- \\
w 2) / w 1(\%)\end{array}$ & $\begin{array}{c}\text { Average } \\
\text { moisture } \\
\text { content }(\%)\end{array}$ \\
\hline 1 & 148 & 113 & 23.64 & \\
\hline 2 & 150 & 110 & 26.67 & \\
\hline 3 & 145 & 108 & 25.52 & 25.54 \\
\hline 4 & 150 & 113 & 24.67 & \\
\hline 5 & 149 & 111 & 25.5 & \\
\hline 6 & 147 & 107 & 27.21 & \\
\hline
\end{tabular}

Significance of characteristics of solid waste

Knowledge of physical characteristics and moisture contents percentage is useful for ascertaining the frequency of removal of waste from the generation point as also the problem likely to be encountered during its collection and transportation. The data is also important while designing the transportation equipment and in the selection and design of processing and disposal methods.

\subsection{Collection of Solid Wastes}

\subsubsection{System of collection adopted in Malkapur city}

In Malkapur city „Community Bin System ${ }^{\text {ee }}$ is used for the collection of solid waste. In this system the waste from the bins which are owned by the Malkapur Municipal Council authority is collected. The authority only has decided the location of these bins in different wards as per their convenience for collection and transportation purposes. The workers appointed by Malkapur Nagar Parishad sweep the roads, collect the material and stack it in the nearby bins or open spaces provided in service lanes. In general the spacing between the bins is not more than $100 \mathrm{~m}$ because large spacing might encourage the workers to avoid transporting the wastes to the community bins.

In Malkapur city the community storage is done in any one or combination of the following ways

\section{1) Concrete Pipe Sections}

At some locations in the city concrete pipe sections of about $1 \mathrm{~m}$ diameter and $1 \mathrm{~m}$ height are used which are having both ends open and are placed directly on the ground. While transferring the contents to the transport vehicle, the pipe section has to be tilted turned on its edges to clean the deposited mass and then transported to the vehicles. 


\section{International Journal of Science and Research (IJSR) \\ ISSN (Online): 2319-7064}

Index Copernicus Value (2013): 6.14 | Impact Factor (2014): 5.611

\section{2) Open Spaces}

The solid waste collected from all the open spaces from the street lanes is transported to the disposal site i.e. Khaparkhed Shivar. A size of the open spaces varies from $8 * 10 * 0.25$ vehicle, the pipe section has to be tilted, turned on its edges to clean the deposited mass and then transported to the vehicles.

\section{3) Litter Bins}

These are small sized bins having capacity 50-100 liters provided with handle for lifting. These are used to collect behavioral wastes from the streets i.e. wastes originated from throwing by pedestrians or by people using the streets. These are kept on the road side.

The following table shows the number of all open spaces/dustbins/concrete pipe sections provided in each ward office of Malkapur city.

Table 6: No and types of community bins in each Prabhag offices

\begin{tabular}{|c|c|c|c|}
\hline $\begin{array}{c}\text { Prabhag } \\
\text { Number }\end{array}$ & $\begin{array}{c}\text { Concrete Pipe } \\
\text { Section }\end{array}$ & $\begin{array}{c}\text { Litter } \\
\text { Bin }\end{array}$ & $\begin{array}{c}\text { Open } \\
\text { Spaces }\end{array}$ \\
\hline 1 & & & 12 \\
\hline 2 & & & 7 \\
\hline 3 & & 2 & 10 \\
\hline 4 & 2 & 4 & 14 \\
\hline 5 & & 2 & 12 \\
\hline 6 & & 1 & 8 \\
\hline 7 & & 1 & 5 \\
\hline Total & 2 & 10 & 68 \\
\hline
\end{tabular}

The maximum size of open spaces provided in service lane in Mallkapur city is $15 * 20 * 0.5$ and the minimum size of open spaces is $3 * 4 * 0.3$.

The street cleansing is done by the manual labour in the city. The total no. of labours in each ward office is shown in the following table.

Table 7: No. of workers of SWM in each Prabhag office

\begin{tabular}{|c|c|c|c|c|c|c|c|c|}
\hline $\begin{array}{c}\text { Prabhag } \\
\text { Office } \\
\text { No. }\end{array}$ & 1 & 2 & 3 & 4 & 5 & 6 & 7 & TOTAL \\
\hline $\begin{array}{c}\text { No. Of } \\
\text { Labours }\end{array}$ & 24 & 20 & 21 & 20 & 22 & 15 & 10 & 132 \\
\hline
\end{tabular}

The equipments, which are used by the labours for the street cleansing purposes, by the manual labours, are as follows.

I) Brooms

II) Hand carts

\subsubsection{Frequency of collection}

The waste in the solid state is generated in residential, industrial and commercial establishments. In order to keep the environment clean, it should be removed quickly as in the case of water carriage system of transporting human faces. But this system is cost intensive and also has some other problems. Therefore, like any other city in India, the discontinuous system is adopted in Malkapur city. From table number 4 it is clear that in all Prabhag offices of Malkapur the organic matter in solid waste occupies a large percentage. This organic fraction tends to decompose at a faster rate at the higher ambient temperatures encountered. It therefore becomes necessary to collect and remove this material as quickly as possible. Also to avoid the nuisance of fly breeding etc. The solid waste removal frequency should be high, either daily or at least thrice a week. The table given below shows the frequency of solid waste in all containers in all Prabhag offices of Malkapur city.

Table 8: Frequency of collection

\begin{tabular}{|c|c|c|c|c|}
\hline \multirow{2}{*}{$\begin{array}{c}\text { Prabhag } \\
\text { Numbar }\end{array}$} & \multicolumn{5}{|c|}{ Frequency Of Collection } \\
\cline { 2 - 5 } & DAILY & 2 DAYS & $3-5$ DAYS & 7 DAYS \\
\hline 1 & 2 & 1 & 1 & 1 \\
\hline 2 & 1 & - & - & 1 \\
\hline 3 & 2 & - & 1 & - \\
\hline 4 & 2 & 1 & 1 & 1 \\
\hline 5 & 2 & - & 1 & 1 \\
\hline 6 & 1 & 1 & - & - \\
\hline 7 & 1 & - & - & 1 \\
\hline
\end{tabular}

\section{Types of vehicle used for transportation}

In Malkapur city, transportation of solid waste from collection point to disposal site done in two stages. In the first stage, certain types of vehicle like tractor, Tata 407 collect the solid waste from the collection point and transport it to "Disposal site" where the solid waste is dumped into the pits.

Thus the vehicles are grouped into two categories:

1) In primary collection the solid waste is collected from the stacking point along the sewer lines and dumped in to concrete pipe section and some open spaces with the help of handcart etc.

2) In secondary collection, the solid waste from the concrete pipe section and from the open spaces is transfer to disposal site.

Secondary collection includes the following vehicles:-

1) Tractor: - These vehicles are used to transport waste collected from the dust bin, concrete pipe section, open spaces etc. These have a capacity of 1.5 tons. Each of these cost Rs. 4 lacs.

No. and types of vehicle in Malkapur Nagar Parishad:

The total no. of vehicle in Malkapur city is:-Tractor -2 and Tata $407-1$

Al the vehicle is owned by the contractor and he is responsible for the transportation of all the solid waste in the city. There is no of intermediate transfer station in the city for collection of the solid waste and for the waste to the disposal site.

\section{Disposal and Treatment}

The solid waste collected by the community bin system is transported through their vehicles to the disposal site for its processing. 


\section{International Journal of Science and Research (IJSR) \\ ISSN (Online): 2319-7064}

Index Copernicus Value (2013): 6.14 | Impact Factor (2014): 5.611

\subsection{Disposal site in Malkapur city}

In Malkapur city the collected SW is transferred to the disposal site which is on Malkapur Bypass, road near Hotel Surya. The disposal site has $400 \mathrm{~m} * 400 \mathrm{~m}$ in area. Earlier on this site there was 10 to $15 \mathrm{ft}$. depression i.e. low lying area which his now rising up by dumping up all the SW from the city. There is no segregation of SW before its dumping. The SW is dumped in the mixed form without any segregation. Tractor or Tata 407 is used to dump the garbage to the disposal site. The reason behind choosing this site for garbage dumping was that this site is away from the city limits and therefore is fewer nuisances to the citizens. Also the site is connected with roads, which can be accessed during all types of weather conditions.

Dead animals and hazardous waste is allowed to dump at this site in the pits of sizes i.e. $7 * 7 * 1.5 \mathrm{~m}$. The no of pits at the site are 11. There are no special trucks and other vehicles, which are used to transport this hazardous waste and dump it in pits prepared by the Malkapur Nagar Parishad.

For the disposal of biological waste from hospital. The Malkapur Nagar Parishad has no special provision. Government hospital adopts their own methods from the disposal of biological waste. But the private hospitals are having no special provision fro the disposal of the biological waste and they are dumping this waste directly in to the open spaces or in concrete pipe sections of Malkapur Nagar Parishad.

\section{Analysis}

The study of ,Solid Waste Management" of Malkapur city as per the methodology adopted was completed and the data regarding the organizational structure, quantity, quality, collection, transportation, treatment and disposal of solid waste was collected. The critical analysis of the data collected was done and the points, which emerged from the analysis, are as follows.

\subsection{Regarding the Organizational Structure}

1) After observing the existing organizational structure of Solid Waste Management in Malkapur city, it is clear that it is a line type organization. Therefore, there is a clear- cut flow of authority and responsibility. Each person knows to whom he is responsible and who is responsible to him. Therefore, there is no confusion in coordination.

2) Under the Chief Officer, there is a) Medical Health Officer b) Sanitary inspector. The Contractor is the person working for Nagar Parishad on the contract basis for transportation of SW to disposal site. Some rules and regulation and condition are laid on the contractor by the Nagar Parishad Super tending Sanitary Inspector take care of the solid waste from different Prabhags of Malkapur city and are responsible for picking and lifting from containers, dust bins etc. The person under the Medical Health Officer is the super tending Health Officer. Under the Super tending Officer, four Prabhag officers are allotted who super wise the collection of the solid waste. One foreman for each Prabhag is allotted and below the foremen there are the workers and the sweepers who collected all the solid waste.

\subsection{Quantity of Solid Waste}

Referring table no. 1 and table no. 2 the data can be further tabularized in the following manner.

Table 9: Analysis of quantity of solid waste:-

\begin{tabular}{|c|c|}
\hline $\begin{array}{c}\text { Prabhag } \\
\text { Number }\end{array}$ & $\begin{array}{c}\text { Per Capita Generatin Of SW } \\
\text { GM/Capita/Day }\end{array}$ \\
\hline 1 & 240 \\
\hline 2 & 228 \\
\hline 3 & 205 \\
\hline 4 & 209 \\
\hline 5 & 216 \\
\hline 6 & 220 \\
\hline 7 & 212 \\
\hline
\end{tabular}

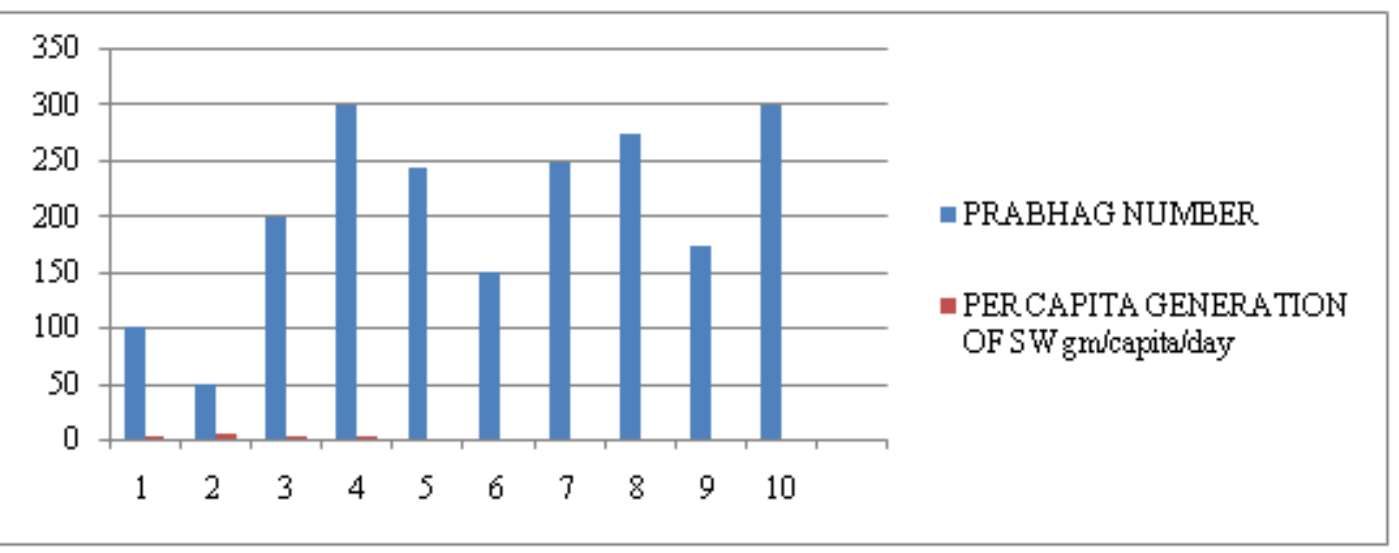

1) In table no. 10 , column no. 2 shows per $\mathrm{m}^{2}$ generation of SW per day. It is obtained by dividing the total quantity of SW collected each Prabhag office by the area of respective Prabhag office. The average of all values was found out to be 70.609 gm per $\mathrm{m}^{2}$ per day, which is the average value of per $\mathrm{m}^{2}$ generation of SW in Malkapur city. This value is helpful in the ,Quantity Forecaste if there is further increase in the boundary limits of Malkapur city. If this value is multiplied with a new value of the area of the city, the total quantity of SW generated in the city can be obtained.

\section{Volume 4 Issue 11, November 2015}




\section{International Journal of Science and Research (IJSR) \\ ISSN (Online): 2319-7064}

Index Copernicus Value (2013): 6.14 | Impact Factor (2014): 5.611

2) In the column number 3 of table no. 10 the values of per capita generation of SW per day of each ward office are given which are obtained by dividing average quantity of SW generated in each ward by the respective population of each ward office. The average of all values is found to be $229.7 \mathrm{gm} /$ capita / day. This value, also, is further useful in ,Quantity Forecaste of SW in Malkapur city. If this value is multiplied by the increased population, the total quantity of SW generated in Malkapur city can be obtained.

3) The total area of Malkapur city is $13.6 \mathrm{Km}^{2}$, and the total SW generated in the city is 24.06 tons/day. Therefore the SW generated per $\mathrm{m}^{2} /$ day is $24.06 / 13.6=$ $1.79 \mathrm{gm} / \mathrm{m}^{2} /$ day.

4) In the column number 3 of table number 10 , it is observed that per capita generation of SW is high in ward offices having high standard of living, for e.g. the ward offices like those situated in front of main hospital of municipal hospital, where the standard of living is high the per capita SW generation is $282 \mathrm{gm}$ /capita/day.

\subsection{Quality of Solid Waste}

The data collected from Malkapur city indicates that due to the common practice of using fresh fruits and vegetables, the waste contains a high organic fraction, which makes frequent collection and removal of solid waste from the collection points a necessity. Also the „Pie Diagrams ${ }^{\text {ee }}$ for physical characteristics of SW indicate that the solid waste contains an appreciable quantity of ash, fine earth, bio resistant materials. This is mainly due to the practice of adding street sweepings, due to which the density of solid waste is between.

As paper, glass, plastics are commonly recycled, only that fraction, which is in an unrecoverable form, remains in the waste. From table number 3 it is clear that the percentage of plastic and paper is higher in areas where standard of living is high, i.e. Prabhag no. 1 and Prabhag no. 9 Area having large number of small scale industries e.g. Prabhag no. 3 and Prabhag no. 4 etc. generates a high percentage of metal. In some areas like Prabhag 8 , the biodegradable content is very high as it includes the Athoudi Bazar area a vegetable market etc. more collection of solid waste is required.

None of the Prabhag in Malkapur city is sorting out the solid waste i.e. combustible waste and non-combustible waste, but instead they only dump that waste to the disposal site. So the solid waste collected at the disposal site is in the mixed form. The moisture content of the solid waste collected at the transfer station is $25.54 \%$ [on wet basis]. But the aerobic decomposition of the solid waste can proceed at any moisture content between $30-65 \%$ if adequate in aeration can be provided. But at the disposal site the moisture content is less than this percentage and also adequate aeration is not provided, therefore Aerobic Decomposition is not practiced at this site. Also to provide optimum condition for microbial action in composting, the moisture content should be maintained between $50-50 \%$ by weight therefore no composting is done.

\subsection{Transportation and Collection}

After collecting the data from the municipal council and Prabhag offices in Malkapur city, the total capital cost which includes the cost of the concrete pipe sections and litter bins which is as follow:- 64200Rs.

Vehicles - Total no of vehicle -3 (by contractor)

Therefore Total Capital Cost $=\mathbf{6 4 2 0 0} /$ -

\section{A) Labour Charges}

Total number workers $=237$ Daily wages of labours $=$ Rs. 150

Therefore Total wages of labours $=237 * 150=$ Rs.35550/Therefore Total labour charges $=$ Rs. 35550/-

\section{Maintenance Cost}

All the maintenance such as maintenance of the tractors and Tata 407 charges are taken as $20 \%$ of capital cost that comes to be $12840 \mathrm{Rs}$.

\section{Cost Analysis}

Transportation of SW by contractor per year is Rs. 7 lacs. The total labour charges for the municipal corporation are 35550.00 Rs. Per day But these labours are also used for the cleaning the sewers. Therefore half the expenses for total labour cost will be for sewer cleaning. Therefore the labour charges for SW will be $35550 / 2=17775.00$. The total SW generates in Malkapur city is 24.06 tons. Hence SW charges for collection of one ton of SW $=17775 / 24.06=741.00 \mathrm{Rs}$. Per ton. The expenditure on the collection and transportation of solid waste in Mumbai was found out to be Rs. 450/- per ton.

The transportation charges per year for SW transportation are 7 Lac. Hence transportation charges per day $=700000$ / $365=1917.00$. Therefore transportation charges for 1 tons $=$ 1917 / 24 = 80 Rs per ton.

Total cost for $\mathrm{SW}=$ cost of collection + cost of transportation

$741+80=821 \mathrm{Rs} /$ ton /day

So the collection and transportation charges for SW / ton / day $=821$ Rs. If we compare the collection and transportation charges for SW / ton/day with Mumbai than we find that the charges are really high. So if the SW generation increases in the near future than the cost of its collection as well as transportation will also increase. The above cost analysis is tentative and may vary as per condition.

\section{Conclusion}

After studying the Solid Waste Management in Malkapur city from the collection and transportation point of view, we come to the conclusion that the performance of and the efficiency of SWM in Malkapur city can be improved if the summary of suggestions and solutions as stated is implemented.

1) Municipal agencies spend a significant portion of their budget on Solid Waste Management, for obtaining good results allocation of funds be increased and a rationalized tariff structure be introduced. 


\section{International Journal of Science and Research (IJSR) \\ ISSN (Online): 2319-7064}

Index Copernicus Value (2013): 6.14 | Impact Factor (2014): 5.611

2) The waste characteristics indicate the necessity of frequent collection and transportation of waste, SW should not stay ideal for more time as moisture content $\%$ is higher.

3) Work norms for workers at various levels be aid down. Continuous monitoring of work is necessary to ensure improved performance.

4) Presently satisfactory performance is not obtained from the contractor of SW mainly due to use of improper vehicles on ill planned routes. It is hence necessary to use suitable vehicles and optimize the transportation routes. Prompt maintenance of vehicles will ensure improved performance and per annum cost of contract will be reduced.

5) Wastes are mostly disposed of by dumping in low lying areas, which can cause a number of problems. Sanitary and filling needs to be practiced to avoid these problems.

6) The bylaws are very old and inadequate and need to be replaced by more comprehensive enactment. Community participation is involved by involving the citizens in decision making at the local level and by a sustained campaign for public awareness.

7) Training programs should be run for staff at all levels to ensure better operation of the system.

8) If the methods of Vermiculture is introduced in disposal of SW disposal of solid waste is easier.

9) Alternative energy can be created by using the SW.

10)Rag pickers if given numeration can help in the collection of solid waste.

11)Calorific valve of waste i.e. density can be reduced by sorting SW at community bins so that other method of disposal can be used like incineration.

12)Total SW is not lifted by contractor that why conge station of big nalas because of which flooding will occur which may cause damage to the people residing on the bank of the nalas.

13)Biological waste should be treated separately due to their hazardous nature.

\section{References}

[1] Bhawalkar Uday S. (2005), "Vermiculture: a boon for Biological Waste conversion," Paper presented in News paper "The Hitvada".

[2] Dakhave Dilip (2005) Paper presented in Daily Times of India.

[3] Mr. Ajit Jain (2004) "Solid Waste Management in Mumbai city" article from United Nation Development Programme.

[4] Pardeshi D.B. (2005), "Solid Waste Management of Pune Municipal Corporation" Paper presented in The Outlook Magazine.

[5] Prof. Jain "Solid Waste Management \& Case study of Pune City".

[6] B.C.Punmia "Solid waste Disposal".

[7] Tata Mcgraw Hill Publisher "Solid Waste Management", Solij Arceiwala "Vermiculture" $\left(2^{\text {nd }}\right.$ Edition).

[8] Garg \& M.C.Garawhill Publication (4 ${ }^{\text {th }}$ Edition) Chapter:- "Effects of water mains on human life." 